\title{
АНАЛІТИЧНИЙ ПІДХІД ДО ВИБОРУ ТОПОЛОГІї НЕЙРОСІТОК ПРИ РОЗВ'ЯЗАННІ ПРИКЛАДНИХ ЗАДАЧ
}

\begin{abstract}
Анотація: На основі розробленого реляційного класифікатора запропонований універсальний підхід до вибору топології нейромереж, що задовольняють критеріям вирішення прикладної проблеми / задачі.

Ключові слова: Персептрон, Нейротехнології, Штучний нейрон, Штучна нейромережа, Алгоритм зворотного поширення помилки, Навчання нейромережі, Топологія нейромережі, Багатофункціональне середовище, Рейтингове оцінювання, мультиагентна система
\end{abstract}

Хронологія та характеристика проблели. На початку 40-х років минулого століття з'явилися дві фундаментальні роботи, в яких вперше формалізуеться поняття штучного нейрону (ШН) і штучной нейронної сітки (ШНС) - це робота У. Мак-Каллоха та У. Піттса [43] про логічне числення ідей та нервової активності та фундаментальна праця Н. Вінера [4] і його колег про подання складних біологічних процесів математичними моделями (в подальшому закріпленому у терміні “кібернетика"). 3 появою запропонованого Ф. Розенблаттом одношарового персептрона [50] (який використовують для розпізнавання образів, прогнозування погоди тощо), а в подальшому розробленої на основі дельтаправила - формули Уідроу і побудованого на принципово нових засадах адаптивного лінійного елемента - Адаліни Уідроу Б. і Хофрфа М. [54] значно підвищуеться зацікавленість на комерційному рівні у підтримці розробок в галузі нейротехнологій (НТ). Цьому в значній мірі сприяв запропонований Д. Хеббом перший алгоритли навиання нейрона [31].

Проте вже проведені у 1963 році під керівництвом Петрова А.П. в Інституті проблем передачі інформації АН СРСР дослідження задач, “важких" для персептрона [10], явилися відправною точкою для Бонгарда Н.Н. [3], щоб "порівняно невеликою переробкою алгоритму (персептрона) виправити його недоліки”. Саме ці дві роботи і стали запорукою того, що перша хвиля ейфорії відносно ШНС була пригальмована в CPCP.

А наприкінці 60-х і майже до середини 70-х років минулого століття спостерігаеться вже різке спадання активності у розвитку НТ та їх прикладного застосування, яке було викликане спостереженими Мінським М. і Пайпертом С. [44] обмеженнями у роботі (моделювання виключно найпростіших логічних функцій, складності у навчанні та перенавчанні тощо) і пов'язаними з інваріантністю подання (так звана проблема “парності" та “один у блоці") штучного нейрона (ШН) Мак-Каллоха і Піттса, а також перших моделей одношарового персептрона Розенблатта $\Phi$.

(c) Л.С. Ямпольський, 2012 
і адаліни Уідроу Б. і Хофра М. I хоча у дослідників НТ було розуміння можливості будувати багатошарові сітки з, очевидно, більш широкими властивостями, але залишалося нез'ясованим питання щодо навчання схованих шарів. Проте, окремі дослідження в галузі НТ продовжувалися, і серед них, в першу чергу, треба відзначити самоорганізуючу НС - конгнітрон (та неокогнітрон), запропонований Фукушимой К. $[24,25]$ і призначений для інваріантного розпізнавання образів (досягається при запам'ятовуванні практично усіх станів образу), а також фундаментальні розробки Хопфілда Д. [34, 35] з перспективною і надзвичайно важливою для просування НТ на комерційний ринок ідеєю створення моделі $H C$ з оберненили зв'язкали, яка уявляе собою мінімізуючу енергетичну систему. Крім того, необхідно відзначити ряд праць Кохонена Т. [37, 38], в яких обгрунтовуеться можливість створення моделей НС, які навиаються без учителя (салоорганізуючі карти Кохонена) і використовуються в задачах кластеризації, візуалізації та інших для попередньої обробки даних. Всі ці дослідження набули значного розвитку в реалізації можливості відтворення спотворених або зашумлених даних і базуються на природній властивості мозку використовувати асоціативні зв'язки при пошуку інформації за допомогою ключа послідовності бітів, яка порівнюеться зі всіма ключами інформації, що зберігається. Такий вид пам'яті дістав назву пал'яті, щз адресуеться за злиістол. Якщо в моделі обчислень фон Неймана звертання до пам'яті є доступним тільки за допомогою адреси, яка не залежить від вмісту пам'яті, і більш того, якщо допущена помилка в обчисленні адреси, то може бути знайдена зовсім інша інформація, то асоціативна пам'ять (що адресуеться за змістом) е доступною по указанню заданого змісту. Значний внесок у розв'язання проблеми асоціативного навчання і створення гетеро - авто- і двоспрялованої асоціативної пал'яті, а також відтворення принципів конкурентного навчання зробили також Андерсен Дж. [17], Гроссберг С. [26] і Коско. Б. [39].

Тільки з появою запропонованого в дисертації Вербоса П. [53] і паралельно в роботі Галушкіна О. I. [5], але спочатку залишеного поза уваги дослідниками, а в подальшому розвиненого Румельхартом Д., Хінтоном $Г$. і Уільямсом Р. [51] та незалежно і одночасно Барцевим С. I. та Охоніним В. О. [2, 18] методу навчання з використанням алгоритлу зворотного поширення похибки (АЗПП) з'явився потужний теоретичний фундамент для конструювання ефективних багатошарових ШНС. Розпочався період вибухової зацікавленості до ШНС, які навчаються.

Нарешті, великого значення набувають сітки з радіально-базиснили фрункціяли (РБФ-сітки), що уявляють собою спеціальний тип ШНС з прямими зв'язками і основне призначення яких - апроксимація та інтерполяція багатомірних функцій для розв'язання, зокрема, задач прогнозування. Вони запропоновані Повеллом М. [49] і спираються на математичну основу теорії апроксимації та інтерполяції багатовимірних фонкцій, раніше розробленої Айзерманом М.А., Браверманом Е.М. і Розоноером Л.I. [1]. Суть математичної основи базуеться на тому, що скільки 
завгодно точна апроксимація функцій досягаеться шляхом комбінації радіально симетричних функцій.

Сьогодні важко уявити область досліджень, будь то технічне або технологічне проектування, діагностування, генетика, біоніка, авіоніка, економіка, ергономіка, комунальне господарство, транспортні задачі і багато інших застосувань, де би не впроваджувалися НТ. Саме ця зацікавленість з боку користувачів спонукає дослідників в області НТ до створення численних топологій ШНС як спеціального, так і універсального призначення. Проте, багатоваріантність вибору ШНС, в свою чергу, створюе утруднення у прийнятті адекватного рішення у користувача, $\mathrm{i}$ це, на наш погляд, і складає основну проблелу використання НT.

Ускладнення проблели. Вище наголошувалося на тому, що після “перевідкриття" і суттевого доопрацювання Румельхартом Д., Хінтоном Г. і Уільямсом Р. і незалежно та одночасно Барцевим С. І. та Охоніним В. О. методу навчання з використанням АЗПП наприкінці минулого початку теперішнього століть створилися підстави до “ренесансу" НТ із все зростаючою зацікавленістю з боку користувачів і задоволенням попиту новими розробками у топологіях ШНС. Останне відбувається двома шляхами:

1. За рахунок використання сполучень, модифікацій і розширень вже існуючих моделей ШНС;

2. Створенням моделей ШНС на нових архітектурних, структурних і топологічних принципах побудування і методах навчання або використання їх для обслуговування інших оптимізаційних алгоритмів, зокрема, генетичних.

Яскравим представником першого може служити сполучення двох ШНС: Кохонена і Гроссберга з новил летодол навчання -“зустрічного поширення" (ЗП), запропонованим та розвиненим Хехт-Нільсеном Р. [30]. Такий симбіоз різних ШНС дозволив покращити властивості результуючої сітки (зменшення часу навчання; можливість роботи як з неперервними, так і з двійковими сигналами; блокове побудування сітки шляхом каскадування спеціалізованих модулів тощо) і розширити сфери застосування (апроксимація функцій, розпізнавання, обробка і відновлення зображень, класифікація). Існує два різновиди двошарових ШНС ЗП: шар Кохонена - шар Гроссберга та салоорганізуюча карта Кохонена - шар Гроссберга (різниця в організації схованого шару i, відповідно, в способі навчання його нейронів) [27].

Іншим прикладом розробок другого шляху розвитку ШНС е створення на базі ідеї сітки Хопфілда з додаванням спеціального модуля нелінійного перетворення нової парадигми, що працюе з аналоговими сигналами - “синергетичного колn'ютера" (CK), запропонованого засновником синергетики Хакеном Х. [28]. Цей комп'ютер відноситься до асоціаторів з інтерпретацією образів, які в ньому зберігаються, як локальні енергетичні мінімуми. Перевага над сіткою Хопфілда - відсутність не- 
стійких станів завдяки наявності динамічного модуля, що збігається до одного з базових векторів.

Суттеве скорочення витрат на пам'ять і об'єм необхідних обчислень досягається в сітиі Хеллінга [42], в якій замість образу, що зберігається у пам'яті, на виході видається тільки його номер. Тому, на відміну від сітки Хопфілда, місткість сітки Хеммінга визначаеться не розмірністю вхідного сигналу $N$, а кількістю нейронів шару $L$ на виході. Крім того, перевагою сітки Хеммінга $е$ те, що залежність між кількістю нейронів і кількістю з'єднань в сітці Хеммінга лінійна, тоді як у Хопфілда - квадратична, і при однаковій емності з сіткою Хопфілда перша буде містити значно менше сполучень між нейронами.

Ще одни приклад створення нової топології за рахунок використання базової моделі багатошарового персептрона прямого поширення являе собою ШНС з елелиентали затрилки сигналу (ШНС 3С). Основне призначення - краще опрацювання (класифікація) зсунених у часі образів (як правило, мовних сигналів), які надходять на вхідний шар із згасанням у часі. Так, оскільки корисна мовна інформація часто подається згасаючою у часі в середовищі перешкод (паузи між надходячими фронемами, зашумлення тощо), а тривалість окремих фонем може сильно коливатися, ШНС ЗС повинна однаково ефективно опрацьовувати такі фонеми, тобто бути робастною до зовнішнього зсуву надходячих на сітку образів $[41,52]$. Відмінність такої сітки полягає в наявності можливості створення за рахунок елементів затримки або у самих нейронах, або між схованими шарами тимчасових копій надходячих сигналів, через що на нейрони наступного шару подаються не тільки самі образи, але й їх копії. Цього принципу дотримуються всі шари ШНС ЗС, завдяки чого і досягається робастність сітки до часових спотворень у вхідних образах.

Представником другого шляху може служити ШНС, яка дістала назву лашини Больцлина [15, 32]. Якщо сітка Хопфілда збігається до локального мінімуму, то в новому різновиді ШНС збіжність має відбуватися у глобальному мінімумі, а оскільки на шляху до цього сітка проходить локальні мінімуми, то існуе ймовірність “зависання" в них. Тому по мірі просування до глобального мінімуму на кожному локальному мінімумі алгоритмічно задається збільшення “умовної енергії”, достатньої для подолання локального максимуму. Надалі енергія "розгойдування" сітки поволі зменшуеться по мірі наближення до глобального мінімуму. Ця ідея і реалізована в машині Больцмана, сполучаючи детерміновану сітку Хопфілда з ймовірнісним/стохастичним правилом навчання, яке дістало назву відпалу. Найчастіше цей різновид ШНС застосовуеться в задачах класифікаціі/розпізнавання невідомих або спотворених образів. Серед переваг - можливість виходу з локальних екстремумів, серед недоліків - трудомісткість пов'язаних з алгоритмом обчислень $\mathrm{i}$, як наслідок, суттеві обчислювальні та часові витрати.

Трохи зменшує цей недолік лишина Koшi [46], в якій за рахунок використання в алгоритмі розподілу Коші можна скоротити час навчання; 
проте у порівнянні з персептроном цей час залишається занадто великим.

Класом ШНС, які яскраво доводять свою причетність до другого шляху розвитку суттевими відмінностями від сіток Хопфілда як структурно (може мати декілька шарів з наявністю власних зворотних зв'язків у нейронів), так і особливостями навчання (матриця ваг може бути несиметричною, а навчання є контрольованим шляхом використання АЗПП), слугують неперервні і дискретні диналічні рекурсивні сітки (ДРС) $[48,16,15,50]$. Наявність зворотних зв'язків між нейронами різних шарів і шару на виході включно забезпечуе цьому класу ШНС додаткові позитивні властивості, яких неможна досягти в статичних багатошарових ШНС прямого поширення: можливість роботи з образами, параметри яких змінюються в часі. Дискретні ДРС поділяються на:

- повнозв'язні $[48,15]$ (застосування: аналіз та опрацювання послідовностей, ідентифікація нелінійних динамічних об'єктів);

- частково-рекурсивні - багатошарові персептрони, доповнені контекстним шаром, кількість нейронів якого співпадае з кількістю виходів ШНС. Останне має місце в сітці Джордана М. [36] (застосування: розпізнавання і класифрікація образів, прогнозування часових рядів, а також більш ефективне в порівнянні з ШНС прямого поширення асоціювання надходячих на вхід образів з послідовностями на виході - так зване “проковзне” вікно; недолік - повільна збіжність і виникаючі через це проблеми сталості) або в модифікованій версії цієї ШНС - сітиі Еллина Дж. [22] з сигналами зворотних зв'язків не вихідного шару, а з виходів нейронів контекстного шару з кількістю нейронів, співпадаючою з кількістю нейронів схованого шару;

- локально-рекурсивні з лінійною структурою як багатошаровий персептрон або як сітка радіальної основи, в яких рекурсивність завжди обмежуеться одним нейроном і інтерпретуеться як фільтр із скінченою або нескінченою імпульсними характеристиками [45].

Представниками нового класу ШНС прямого поширення з можливістю за необхідності розширювання своєї архітектури в процесі функціонування е каскадно кореляційні сітки (ККС) з лінійними або/та нелінійними активаційними функціями нейронів і використанням алгоритму навчання з будь-яким правилом (дельта-правило, АЗПП тощо), запропоновані Фалманом С. і Леб’єром К. [23]. Навчання ККС повторюється до досягнення бажаної точності для всіх пар образів і базується на: покроковому інкрементному уведенні нейронів у сховані шари, які з'являються тільки після уведення нових нейронів; навчанні знов уведених нейронів при зберіганні ваг нейронів, які вже до того були у сітці. Переваги ККС: відсутність апріорного вибору архітектури сітки, бо як вихідна береться найпростіша з вхідним та вихідним шарами, а далі нарощуеться, поки сітка не визначить задовольняючу критеріям архітектуру; відсутність конкуренції між нейронами через їх незв'язність 
значно скорочує процес навчання в порівнянні з іншими топологіями сіток; з поданням нових образів може не відбуватися перенавчання всієї сітки, а тільки шляхом корекції зв'язків нейронів вхідного та схованого шарів; процес навчання сітки значно спрощуеться в обчислювальному сенсі, бо коректуються ваги тільки одного шару, і сигнали у сітці проходять тільки в одному напрямі. Призначення: основні переваги ККС проявляються в повній мірі при застосуванні в обчислювальних середовищах з використанням паралельних обчислень.

Розв'язання “дилеми стабільності-пластичності” (за Гроссбергом С.) запропонованою двошаровою нейросіткою адаптивної резонансної теоpiï (AРТ) Карпентером Г. і Гроссберогом С. [20] дозволяє адаптивно навчатися при надходженні нових даних із збереженням стабільності щодо гарантії неруйнування попередньо накопичених даних, з одного боку, і достатньої пластичності відносно визначення суттевості нових надходжень, з другого. Основне призначення АРТ - моделювання володіючих високим ступенем паралелізму архітектур самоорганізованих ШНС розпізнавання образів, відтворюючих їх біологічний і поведінковий контексти. Основні властивості сіток АРТ - стабілізація і стійкість процесу навчання (який є скінченим) і сталість процесу пошуку. В залежності від виду вхідних змінних і способу їх опрацьовування розрізняють АРТ: з двійковими вхідними векторами (АРТ-1); з двійковими та неперервними вхідними векторами (АРТ-2); для моделювання біологічних процесів (АРТ-3), з двійковими вхідними векторами з використанням нечіткої логіки (Fuzzy-APT)[21].

Вважається, що генетичні алгоритли (ГА) були запропоновані та досліджені Холландом Дж. в 1975 році [33]. Проте, майже 10-ма роками раніше розроблений Івахненко О.Г. лиетод групового урахування аргулиентів (МГУА) [7-9] базувався на використанні одно- та багаторядних фільтруючих за певними критеріями алгоритмів саме для визначення “моделей оптимальної складності”, що і являли собою ніщо інше, як процедуру генетичного добору за певними ознаками якості. Відмінності МГУА від ГА полягають лише в тому, що родинні хромосоми останнього у МГУА мають вигляд складових поліноміальних попарних сполучень (“батьки”), а нові хромосоми (“діти”) - відібрані на етапах алгоритмування (кросовер, мутація) проміжні моделі складності в МГУА. Сітки, основані на МГУА [47], при складанні з $m$ шарів можуть реалізовувати поліном степеня $2^{m}$. "Просіюючи" на кожному з етапів багаторядного алгоритму через “решето” критеріїв отримані на попередньому етапі моделі (“особини” за термінологією ГА), можна керувати відбиранням найкращих. Більш того, МГУА є кращим методом для розв’язання задач ідентифрікації та короткострокових прогнозувань, а для довгострокового прогнозування є не тільки найкращим, а й, можливо, унікальним методом, який забезпечує точність прогнозування за великим часом його випередження. Таким чином, як ГА, так і алгоритми МГУА є оптимізаційними і в ШНС можуть застосовуватися для пошуку оптимальних синаптичних ваг сіток зворотного поширення обмеженої розмірності [55] 
, а також для визначення оптимальної структури ШНС під конкретну задачу [29]. Крім того, заслуговують на увагу дослідження, пов'язані з використанням ГА-підходу до генетичного програливання [40]. В загальному вигляді ГА можна подати наступною послідовністю кроків:

1. Подання всіх змінних, які оптимізуються, у вигляді бінарного або дійсного (в залежності від модифрікації методу) ланцюжка параметрів - "хромосоми”, і далі випадковим чином створюеться “популяція хромосом";

2. Оцінювання кожної хромосоми з популяції за цільовою функцією;

3. Сортування всі оцінювань. Якщо кількість виконаних ітерацій не перевищуе заздалегідь задане значення, то перехід до наступного кроку. Інакше рішенням є найкраща хромосома за результатами сортування на цьому кроці;

4. Відібрані на попередньому кроці найкращі представники популяції складають основу (“хромосом-батьків") для створення за допомогою генетичних операцій (“кросовера” і “мутації) нових хромосом (“хромосом-дітей”). Кросовер визначае рекомбінацію, за якою різні найкращі “хромосоми-батьки" даної популяції обмінюються деякими частинами бінарних ланцюжків. При цьому довільні двійкові розряди довільних хромосом можуть інвертуватися з малою ймовірністю цього процесу;

5. Оцінювання “хромосом-дітей” цільовою фрунццією і розміщення їх в популяцію на місця “гірших” ï представників. Далі - перехід до пункту 3.

Позитивна якість ГА полягае в його універсальності - він дозволяе працювати як з неперервними, так і дискретними параметрами, i можливість його застосування не залежить від виду цільової функції; крім того, ГА спроможний знайти глобальний екстремум, тоді як інші алгоритми “зависають” на локальному екстремумі. Нарешті, ГА можна застосовувати на будь-якому етапі синтезу нечітких моделей, особливо у тих випадках, коли використання градіентних методів неможливе.

До недоліків слід віднести досить низьку швидкодію, яка значно знижуеться із зростанням кількості параметрів, що оптимізуються; крім того, ГА має велику кількість своїх параметрів - розмір популяції, довжина хромосоми, ймовірності кросовера і мутації, кількість "хромосомдітей" тощо. Істотним недоліком $е$ також явище "стогнації" як наслідок “невдалого” вибору параметрів з виродженням популяції або відсутністю прогресу.

Отже, розширення інструментального “асортименту" різновидів ШНС, дозволяючи більш “тонко” і професійно підходити до вибору моделі/топології ШНС, адекватної умовам обслуговування прикладної задачі, разом з тим ускладнюють цей процес через його багатоваріантність. За недостатньої професійної підготовленості користувача це може призводити до значних додаткових матеріальних (апаратних, обчислювальних) i/aбо часових витрат. 
Постановка задачі. Як і у будь-якій іншій галузі знань, інтелектуальний прорив у широкому використанні НТ став можливим, тільки коли для його реалізації були дотримані необхідні і достатні умови (рис. 1):

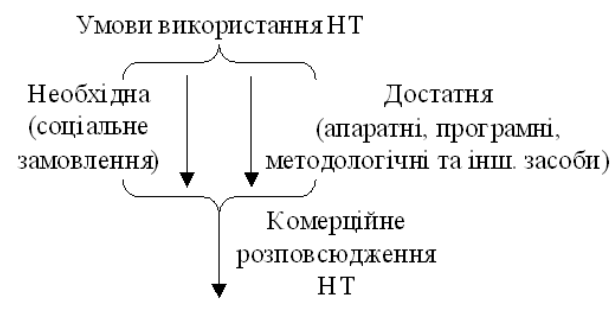

Рис. 1 - Умови комерційної реалізації ШНС

Ця умова виконуеться як завдяки явно вираженої зацікавленості прикладних користувачів у нових підходах до розуміння функцій природного (біологічного) інтелекту шляхом створення математичної моделі самосвідомості та усвідомлення своїх можливостей у розв'язанні складних інтелектуальних задач (необхідна улова), так і досягненням в області інструментальних (апаратних, програмних, методологічних тощо) засобів для побудування ефективних за швидкодією, точністю моделювання і потужності (розмірності) ШНС (достатня улова).

Означення 1. Штучні нейронні сітки - математичні моделі та їх програмні i/або апаратні реалізації, виконані за принципом організації біологічних нейросіток, уявляють собою систему з'єднаних і взаємодіючих простих процесорів (штучних нейронів).

Роль і уявлення про ШНС, які й визначають зростаючий попит на застосування ШНС в різних сорерах життедіяльносмті людини, багатогранні [6]. 3 точки зору:

- лашинного навчання - ШНС уявляють собою окремий випадок методів розпізнавання образів, кластеризації, дискримінантного аналізу тощо;

- лателитичної - навчання ШНС є багатопараметричною задачею нелінійної оптимізації;

- кібернетики - ШНС використовуються в задачах адаптивного управління і прогнозування;

- розвитку обиислювальної техніки - програмування ШНС е способом розв'язання проблеми ефективного паралелізму;

- штучного інтелекту - ШНС е основою філософрської течії конективізму та основним напрямком у структурному підході по вивченню можливостей побудування/моделювання природного інтелекту за допомогою комп'ютерних алгоритмів. 
Отже, обчислювальні системи на основі ШНС володіють якостями, яких позбавлені машини з архітектурою фон Неймана, проте притаманих мозку людини: масовий паралелізм; розподілене подання інформації та обчислень; здібність до навчання та узагальнення; адаптивність; властивість контекстуального оброблення інформації; толерантність до похибок; низьке енергоспоживання.

Апаратна реалізація ШНС - нейроколn'ютер - має суттеві позитивні для широкого впровадження відмінності (як за структурою, так і за класами розв'язуваних задач) від обчислювальних машин, виконаних у відповідності з традиційною архітектурою фон Неймана. Порівняльні характеристики нейрокомп'ютерів і традиційних комп'ютерів наведено у табл. 1.

Таблиця 1.

Порівняльні характеристики традиційних ЕОМ і нейрокомп'ютерів

\begin{tabular}{|l|l|l|}
\hline $\begin{array}{l}\text { Категорія } \\
\text { порівняння }\end{array}$ & $\begin{array}{l}\text { ЕОМ } \\
\text { традиційної архітектури }\end{array}$ & Нейрокомп’ютер \\
\hline Процесор & $\begin{array}{l}\text { Складний } \\
\text { Високошвидкісний } \\
\text { Одни або декілька }\end{array}$ & $\begin{array}{l}\text { Простий } \\
\text { Низькошвидкісний } \\
\text { Велика кількість }\end{array}$ \\
\hline Пам'ять & $\begin{array}{l}\text { Відокремлена від проце-- } \\
\text { сора } \\
\text { Локалізована } \\
\text { Адресація не за змістом }\end{array}$ & $\begin{array}{l}\text { Розподілена процесор } \\
\text { Адресація за змістом }\end{array}$ \\
\hline Обчислення & $\begin{array}{l}\text { Централізовані } \\
\text { Послідовні } \\
\text { Програми, що зберігаю- } \\
\text { ться }\end{array}$ & $\begin{array}{l}\text { Розподілені } \\
\text { Паралнельні } \\
\text { Самонавчання }\end{array}$ \\
\hline Надійність & Висока уразливість & Живучість \\
\hline Спеціалізація & $\begin{array}{l}\text { Чисельні та символьні } \\
\text { операціі }\end{array}$ & Проблеми сприйняття \\
\hline $\begin{array}{l}\text { Середовище } \\
\text { функціонуван- } \\
\text { ня }\end{array}$ & $\begin{array}{l}\text { Суворо визначене } \\
\text { Суворо обмежене }\end{array}$ & Без обмежень \\
\hline
\end{tabular}

Основні тези, які складають підгрунтя використання ШНС і нейромоделювання, полягають у наступному:

- нейросітка відтворюе структуру і властивості нервової системи живих організмів - складається з великої кількості простих обчислювальних елементів (нейронів) і володіє більш складною поведінкою по відношенню до можливостей кожного окремого нейрона;

- нейросітка отримуе на вході набір вхідних сигналів і видае відповідну до них відповідь (сигнали на виході $\mathrm{HC}$ ), яка і є розв'язком задачі;

- як і природна біологічна нейросітка, ШНС може навчатися розв'язанню задач через наявність внутрішніх адаптивних параметрів 
нейронів і своєї структури та, змінюючи їх, може міняти свою поведінку;

- місце програмування займає навчання, тренування НC, і для розв'язання задачі не треба програмувати алгоритм;

- нейросітка навчається розв'язанню задачі на деякому “асоціаторі” наборі ситуацій, кожна з яких описуе значення вхідних сигналів НС і бажану для них відповідь. При цьому “асоціатор” задає набір еталонних ситуацій з відомими розв'язками, а НС при навчанні сама находить залежності між вхідними сигналами та відповідями.

Саме широка варіативність ШНС, наявність тонких відмінностей у принципах побудови і функціонування, відсутність строгих класифрікаційних ознак і чітких рекомендацій щодо сфрер застосування і розв'язуваних задач вимагають високої усвідомленості в питаннях вибору топологій ШНС у прикладного користувача, що виявляється не завжди виконуваним, перш за все, через його професійну непідготовленість у галузі сучасних НТ. Отже, розрив між об'єктивною доцільністю використання новітніх досягнень в НТ для розв'язання прикладних задач і суб'ективною непоінфорлованістю кінцевого користувача обмежуе можливості ефективнішого використання ШНС. Через це ШНС використовуються в двох варіантах: будуеться нейросітка, яка розв'язуе певний клас задач; під кожний екземпляр задачі будуеться деяка нейросітка, яка знаходить квазіоптимальний розв'язок цієї задачі. Проте в обох випадках прийняття рішення покладається на користувача.

Покращення ситуації нам уявляеться в наступному:

- формуванні набору вирішних класифікаційних ознак (НВКО) і створенні класифікатора ШНС;

- побудуванні чіткої логічної моделі поетапного синтезу (МПС) ШНС;

- створенні строгої узагальненої лоделі вибору типових топологій (УМВТТ) ШНС для конкретних прикладних задач, що базуеться на формалізованих моделях подання знань [2] з використанням НВКО та агентно-орієнтованого підходу [19].

Означення 2. Набір вирішних класифрікаційних ознак ШНС - така їх мінімально допустима сукупність, яка є необхідною для формалізації процесу подання основних властивостей і вибору задовольняючих топологій нейросіток і достатньою для адекватного обслуговування вимог (критеріїв оцінки) з боку прикладної розв'язуваної задачі.

Означення 3. Модель поетапного синтезу ШНС - така послідовність їх перебирання в просторі НВКО, яка, будучи виконувана користувачем i/або лильтиагентною підсистелою автолитизованого вибоpy (МАПАВ), відтворюе принципи агентно-орієнтованого підходу та автономно дозволяе виокремити топологію/топології ШНС, здатну/здатні задовольнити критерії обслуговування властивостей розв'язуваної задачі. 
Означення 4. Агент/лильтиагент - це програмно-апаратний чи програмно-емуляційний автономний компонент мультиагентної підсистеми, який функціонуе за певним сценаріем/алгоритмом на основі конкретної унікальної послідовності дій в інтересах досягнення поставлених користувачем перед нею цілей.

Твердження 1. Алгоритм дії агента може мінятися і коректуватися по ходу виконання завдання заради досягнення мети.

Твердження 2. Конкретна унікальна послідовність дій (КУПД), що приводить до мети, шукаеться агентом кожного разу з урахуванням вівдповідних критеріїв обслуговування властивостей даної розв'язуваної задачі.

Означення 5. Мультиагентна підсистела (МАП) - це складна система, в якій функціонують два чи більше інтелектуальних агента.

Форлування набору вирішних класифікаційних ознак. Проведений аналітичний перегляд основних напрямків розвитку НТ, а також результати численних досліджень в інших джерелах, присвячених даній проблемі, дозволяють сорормувати НВКО і запропонувати класифікатор ШНС, які в сукупності сприятимуть послідовності обгрунтування вибору відповідностей “розв'язувана прикладна задача - топологічна модель ШНС".

Досвід роботи по створенню агентно-орієнтованого інтерпретатора ШНС дозволяе стверджувати, що наведений нижче перелік $\mathrm{HBKO}$ e і необхідним, і достатнім для розв'язання поставленої задачі і містить:

- тип вхідної інфорлацї - аналогові і двійкові;

- лодель інтелектуального нейрона - Мак-Каллоха-Питтса, одношаровий персептрон, Адаліна, Фукушима, сігма-пі-нейрон, Хопфілда, Гроссберга;

- структуру - прямоспрямовані, зворотного поширення (с прямими, непрямими, латеральними зв'язками, повнозв'язні);

- архітектуру - одношарові (одношаровий персептрон, Адаліна, НАдаліна), багатошарові (багатошаровий персептрон, Мадаліна, сітка на основі МГУА тощо);

- летоди навчання - з вчителем, без вчителя, шляхом самоорганізації, конкурентні, стохастичні, градіентні;

- настроювання ваг - фіксоване і динамічне;

- критерії оцінки - простота реалізації, швидкість та ефективність алгоритму навчання, точність апроксимації, потужність (розмірність) при розв'язанні прикладної задачі, кваліфрікація користувача, наявність локальних мінімумів, можливість фрільтрації та відновлення.

Класифікація штучних нейронних сіток. Структурна схема класифікації ШНС з бажаним НВКО подана на рис. 2. 
Запропонований НВКО потребуе уточнення деяких тверджень, означень:

Означення 6. Аналогова вхідна інфорлація - інформація на вході ШНС, подана у формі дійсних чисел;

Означення 7. Двійкова вхідна інфрорлація - інформація на вході ШНС у вигляді нулів та одиниць.

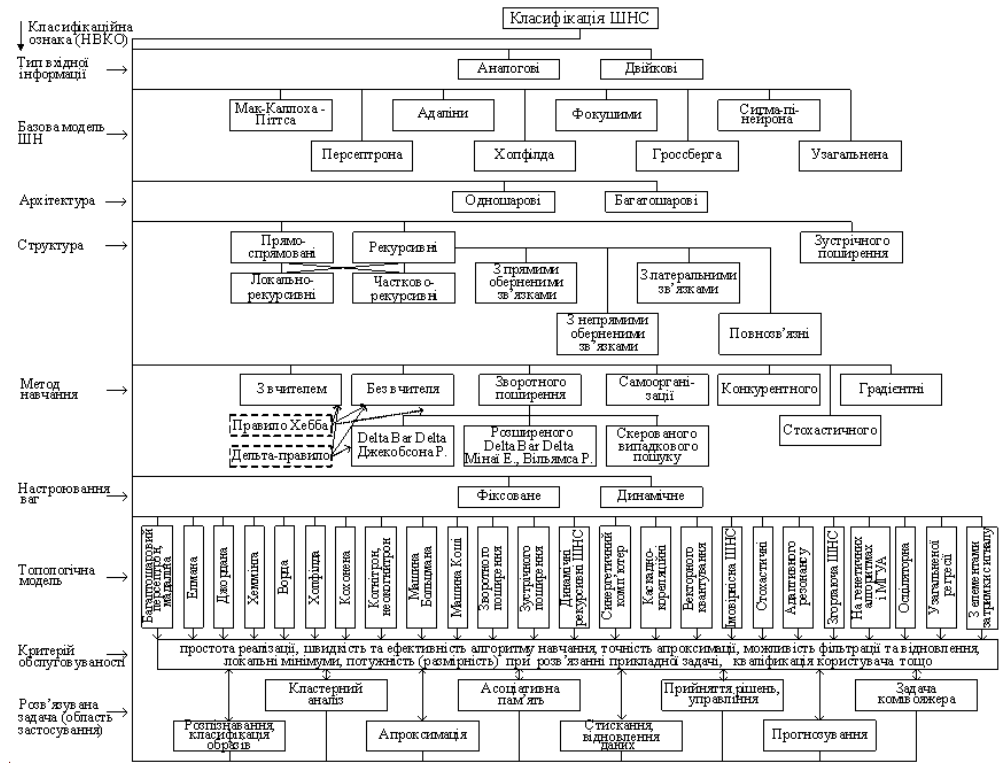

Рис. 2 - Класифікація ШНС з бажаним НВКО

Отже, можна виділити два основних підходи до реалізації НC: цифровиц та аналоговий. Перевагою аналогових реалізацій є: висока швидкодія, надійність та еконолічність. Проте сфера можливого масового використання навчуваних аналогових нейрочипів досить вузка. Це обумовлене великою складністю апаратної реалізації високоефективних навчаючих алгоритмів і необхідністю спеціальної підготовки потенційних користувачів для оптимальної організації адаптивного процесу. У той же час, широке розповсюдження можуть отримати аналогові нейрокомп'ютери/нейросітки з фіксованою або незначно підналагоджуваною структурою зв'язків - нейропроцесори;

Твердження 3. Задача створення нейропроцесорів зводиться до навчання цифрової нейросіткової моделі необхідній поведінці на звичайному цифровому комп'ютері;

Означення 8. Базова лодель ШН - математична та ї̈ програмна i/або апаратна реалізації, на основі яких будуеться ШНС; 
Твердження 4. Архітектура ШНС визначається кількістю шарів і кількістю нейронів у шарі.

3 позицій архітектурного побудування ШНС важливу роль відіграє нелінійність активаційної функцї̈ через те, що, якби вона не володіла даною властивістю або не входила в алгоритм роботи кожного нейрона, результат функціонування будь-якої $n$-шарової НС зводився б до добутку вхідного вектора $\mathbf{X}$ сигналів $x_{i}$ на матрицю вагових коефіціентів. Тобто фрактично така НС була б еквівалентна одношаровій НС з ваговою матрицею $\mathbf{W}$ единого шару.

Означення 9. Активаційна функиія - функція $f_{a}(*)$, яка визначає правило переходу нейрона, що знаходиться в момент часу $\tau$ в стані $g(\tau)$, у новий стан $g(\tau+1)$ при надходженні вхідних сигналів $x_{i}$;

Твердження 5. Структура ШНС визначаеться напрямом та охопленням зв'язків між шарами та окремими нейронами, тобто характером зв'язків.

Визначення кількості проміжних шарів і кількості нейронів в них $е$ важливим при моделюванні сітки. Зазвичай, застосовуючи архітектуру до визначених проблем, використовують загальні правила, зокрема:

1. Кількість входів та виходів сітки визначаються кількістю вхідних та вихідних параметрів досліджуваного об’єкту, явища, процесу, тощо. На відміну від зовнішніх шарів, кількість нейронів прихованого

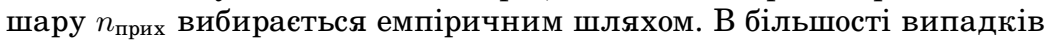
достатня кількість нейронів становить $n_{\text {прих }} \leqslant n_{\text {вх }} \leqslant n_{\text {вих }}$, де $n_{\text {вх }}, n_{\text {вих }}$ - кількість нейронів у вхідному і, відповідно, у вихідному шарах.

2. Якщо складність у відношенні між отриманими та бажаними даними на виході збільшуеться, кількість нейронів прихованого шарі повинна також збільшитись.

3. Якщо процес, що моделюеться, може розділятись на багато етапів, потрібен додатковий прихований шар (шари). Якщо процес не розділяеться на етапи, тоді додаткові шари можуть допустити перезапам'ятовування $i$, відповідно, невірне загальне рішення.

Оскільки всі штучні нейронні сітки базуються на концепції функціонування нейронів, правил та менханізмів їх з'еднань, а також передатних функцій щодо процедури активації, існуе подібність між різними структурами або архітектурами нейронних сіток. Більшість змін походить з різних правил навчання. Таким чином, після того, як визначено кількість шарів і число нейронів в кожному з них, потрібно знайти значення для синаптичних ваг і порогів сітки, які спроможні мінімізувати похибку спродукованого результату. Саме для цього існують $a л$ горитли навчання, де відбувається підгонка моделі сітки до наявних навчальних даних;

Твердження 6. Штучні нейронні сітки не програмуються у звичайному сенсі - вони навчаються;

Означення 10. Навчання з вчителел - таке навчання ШНС, яке припускає існування цільового вектора - бажаного виходу ШНС для 
кожного вхідного вектора і виконуеться із залученням правил навчання: Хебба, дельта-правила/його модифікацій, алгоритму зворотного поширення похибки тощо;

Твердження 7. Разом вхідний та цільовий вектори утворюють навчаючу пару, і зазвичай сітка навчається на деякому сполученні таких пар;

Означення 11. Навчання без виителя - таке навчання, яке відбувається за відсутності цільового вектора, а навчаючий алгоритли при цьому підналагоджуе ваги таким чином, щоб отримати узгоджені вектори на виході ШНС, причому подання досить близьких вхідних векторів дає однакові вектори на виході;

Означення 12. Навчання з використаннял алгоритлу зворотного поширення похибки - це навчання, яке, використовуючи поширення принципів дельта-правила, реалізуе градіентний метод опуклого функціоналу похибки в багатошарових ШНС із структурою прямого поширення на моделях ШН з диференційованими функціями активації;

Твердження 8. Похибка для конкретної топології ШНС з варійовуваними значеннями синаптичних ваг і порогів сітки (так званих вільних паралиетрів топології ШНС) визначаеться шляхом проходження через неї всієї навчальної множини і порівняння спродукованих на виході значень з цільовими/бажаними. Множина похибок утворює фрункцію похибок, яку можна розглядати як похибку сітки. В якості фрункції похибок найчастіше використовують сулу квадратів похибок.

Твердження 9. Мета навчання ШНС за алгоритмом АЗПП полягає в знаходженні на багатовимірній поверхні найнижчої точки, яка відповідатиме глобальному мінімуму.

Для кращого розуміння навчання за алгоритмолм АЗПП потрібно роз'яснити поняття поверхні станів. Кожному значенню синаптичних ваг і порогів сітки (вільних параметрів моделі кількістю $N$ ) відповідає один вимір в багатовимірному просторі. Вимір $N+1$-ий відповідає похибці сітки. Для різноманітних сполучень ваг відповідну похибку сітки можна зобразити точкою в $N+1$-вимірному просторі, всі ці точки утворюють деяку поверхню станів.

Поверхня станів має складну будову і досить неприемні властивості, зокрема, наявність локальних мінімумів (точки, найнижчі в своєму певному околі, але вищі від глобального мінімуму), пласкі ділянки, сідлові точки і довгі вузькі яри. Аналітичними засобами неможливо визначити розташування глобального мінімуму на поверхні станів, тому навчання нейросітки по суті полягає в дослідженні цієї поверхні. Відштовхуючись від початкової конфрігурації ваг і порогів (від випадково обраної точки на поверхні), алгоритм навчання поступово відшукуе глобальний мінімум. Обчислюеться вектор градієнту поверхні похибок, який вказуе напрямок найкоротшого спуску по поверхні з заданої точки. Якщо трошки просунутись по ньому, похибка зменшиться. Зрештою алгоритм зупиняеться в нижній точці, що може виявитись лише локальним мінімумом (в ідеальному випадку - глобальним мінімумом). Складність 
застосування АЗПП полягає у виборі довжини кроків переходу вектора градієнта поверхні похибок, через що або зростає кількість ітерацій і разом з тим час пошуку (при замалих кроках, або епохаx), або зростає ймовірність “перестрибування” оптимального розв'язку чи руху в невірному напрямку (при занадто великих кроках). Ітеративний процес навчання припиняеться або коли пройдена визначена кількість епох, або коли похибка досягає визначеного рівня лалості, або коли похибка перестає злиеншуватись (користувач переважно сам вибирає потрібний критерій зупинення процесу);

Означення 13. Навчання шляхоли салоорганізацї - таке навчання, за яким аналогічні вхідні сигнали збуджують сусідні нейрони, і такий “колективізм” може здійснюватися завдяки оберненим зв'язкам. Ваги змінюються на кожному кроці навчання, i їх змінювання залежить як від сусідніх вхідних образів, так і ймовірнісного розподілення, за яким пропонуються для навчання допущені вхідні образи;

Означення 14. Сітки з фіксованили зв'язкали - такі, у яких коефіцієнти ШНС призначаються відразу, виходячи з умов задачі;

Означення 15. Сітки з диналічнили зв'язкали - такі, у яких в процесі навчання відбуваеться налагодження синаптичних ваг;

Означення 16. Топологія ШНС - це модель нейросітки з певними архітектурою, структурою, методами навчання і настроювання ваг і побудовані на основі певних моделей ШН;

Твердження 10. Топологічні властивості (ТВ) ШНС не змінюються при будь-яких структурно-архітектурних перетвореннях без втрати суттевості певного виду нейросіток. Прикладом ТВ ШНС є розмірність/потужність останніх, що визначається кількісною характеристикою: шарів, нейронів у шарі, а також зворотних зв'язків, входів та виходів сітки тощо.

Означення 17. Топологічний простір ШНС - множина моделей сіток будь-якої топології, в якій через НВКО в той чи інший спосіб визначені граничні значення ТВ ШНС.

Логічна схелка поетапного синтезу ШНС. Наведена на рис. 3 схема містить, з урахуванням запропонованого НВКО, відображення послідовності їх урахування при ітераційній процедурі синтезу ШНС на основі КУПД інтелектуальних агентів в процесі функціонуванні МАПАВ.

Заключна процедура поетапного синтезу ШНС зводиться до перевірки у реляційному перебиранні інтелектуальними агентами умов виконання критеріїв обслуговуваності поточним вектором можливостей конкретної топології ШНС вимог з боку прикладної задачі.

Твердження 11. В мультиагентній системі функції інтелектуалізованих агентів можуть реалізуватися певними топологіями ШНС.

Означення 18. Критерій обслуговуваності - показник задоволення топологією ШНС вимог з боку розв'язуваної задачі і професійної відповідності користувача. 


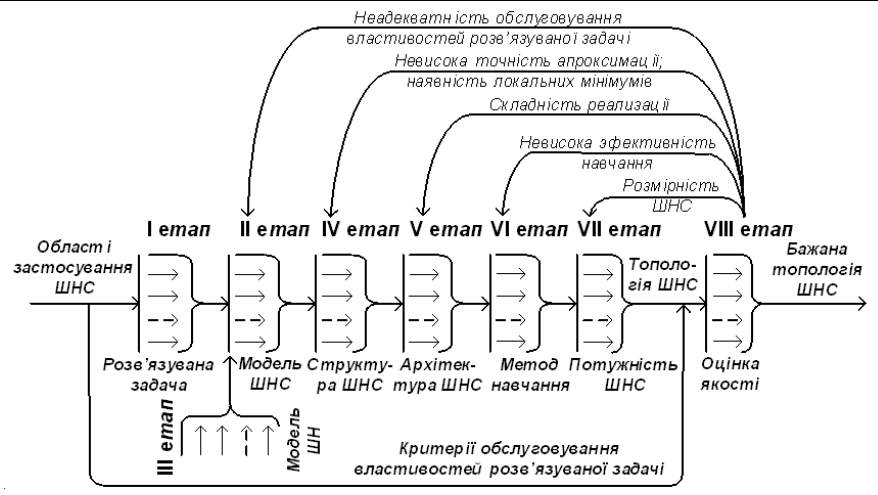

Рис. 3 - Логічна схема поетапного синтезу ШНС

Агентно-орієнтований вибір відповідностей “розв'язувана прикладна задача - топологія ШНС”. На рис. 4 наведена УМВТТ, заснована на реляційних відношеннях [12] між окремими компонентами НРКП, формування якого уявляє першу складність реалізації моделі [13].

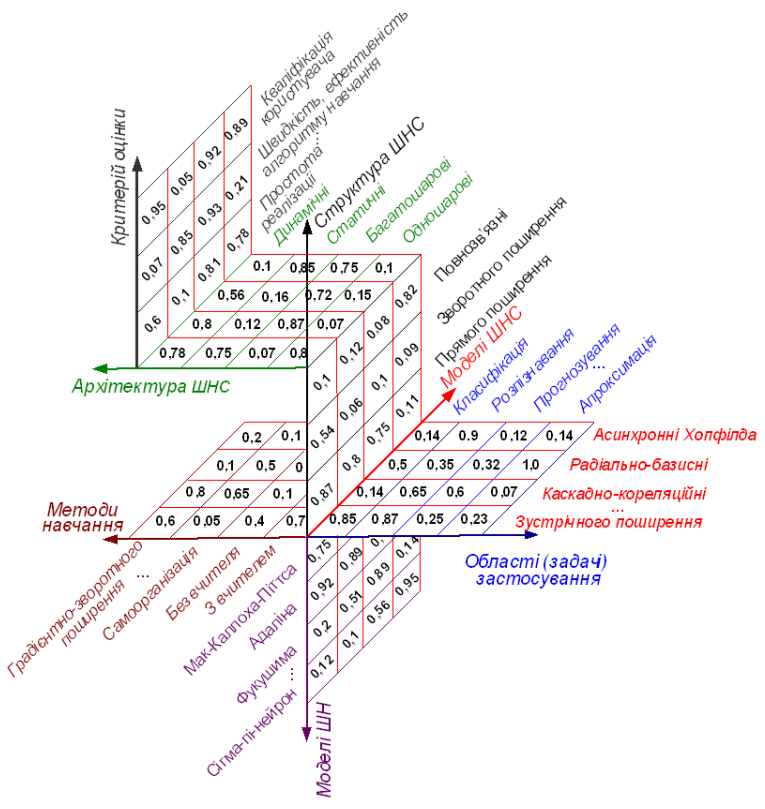

Рис. 4 - Інтерпретаційна УМВТТ ШНС 
Друга складність полягае у кількісному визначенні вагомості реляційних зв'язків між вирішними класифікаційними ознаками і реалізуеться експертним рейтинговим оцінюванням альтернативних варіантів із застосуванням методів ранжирування та попарних порівнянь [14]. Відповідні дослідження потребують глибоких і ретельних проробок щодо однозначності розв'язання цієї частини задачі адекватного вибору ШНС. На рис. 4 наведені умовні кількісні результати попередніх обробіток джерельних даних, які, не претендуючи на строгість експертного оцінювання, можна розглядати як приклад загальної постановки при розв'язанні задачі адекватного вибору ШНС в інтерпретаційній моделі.

Узагальнення та висновки. Можна констатувати, що з найпоширеніших сфер застосування ШНС є розпізнавання образів. Це тим важливіше враховувати через те, що у більшості інших застосувань задача розпізнавання, навіть не будучи метою використання у явному вигляді, все ж припускає цю процедуру при надходячих на вхід образах з наступною їх класифікацією, кластеризацію тощо. Під кластеризацією мають на увазі розбиття множини вхідних образів на класи, коли ані кількість, ані ознаки класів не відомі. Сітка може констатувати, що вхідний образ не відноситься до жодного з виділених класів - це свідчить про те, що з'явилися нові образи з відмінними ознаками від тих, що визначають належність до певного класу. Тобто сітка виявляе нові, невідомі раніше класи образів, виконуючи функції кластеризатора.

3 іншого боку, будь-яке застосування ШНС для розв'язання прикладних задач асоціюеться з механізмом прийняття рішень при керуванні, рівно як і прийняття рішень, в свою чергу, базуеться на перебиранні можливих варіантів і виборі задовольняючого заданий показник ефективності. А це й е визначенням такого стану ШНС, яке відповідае “образу” ефрективного керування [11].

Прогнозування можна віднести до так званої “імпровізуючої” властивості ШНС у вигляді узагальнення і виокремлення схованих взаємозв'язків між даними на вході і виході. Інакше кажучи, якщо у вхідній виборці даних є сховані закономірності їх впливу на змінювання даних на виході, то можна використовувати ШНС як прогнозуючий інструлент. А вже далі, на підставі цієї прогнозуючої функції, ШНС може приймати рішення при керуванні.

В багатьох випадках буває необхідно підібрати для функції, заданої тільки таблично або графіком і відображаючої результати експериментальних даних, аналітичний вираз, відбиваючий ці залежності. Формула ж може виявитися досить складною і некоректною для вимаганої мети (наприклад, функція має бути проінтегрованою, а інтеграл від неї не виражається через елементарні функції). Тоді емпіричні формули для зображення необхідної функції $f(x)$ вибирають наближену функцію $g(x)$ як набір з функцій певного виду, вимагаючи, щоб функція $g(x)$ якомога ближче співпадала з $f(x)$ на деякому інтервалі $(a \leqslant x \leqslant b)$. Нелінійна характеристика при цьому може бути довільною: від сигмоїдальної до будь-якого хвильового пакету, синуса або багаточлена. Від 
вибору нелінійної функції може залежати складність ШНС, але з будьякою нелінійністю сітка залишаеться універсальним апроксилаторол і при коректному виборі структури може досить точно апроксимувати функціонування будь-якого неперервного автомата.

Здатність ШНС до виявлення взаємозв'язків між різними параметрами дозволяє подавати дані великої розмірності більш компактно, якщо останні тісно взаємопов'язані одне з одним. Нейросітки із зворотним процесом - відновлення вихідного образу з його частини або з його спотвореного (зашумленого/пошкодженого) оригіналу - дістали назву (авто)асоціативної пал'яті. Створення на ШНС гетероасоціативної пал'яті дозволяе реалізовувати пам'ять, яка адресуеться за вмістом.

Отже, наведені в статті класифрікатор ШНС, побудований на НВКО, а також запропонована інтерпретаційна модель вибору адекватної топології ШНС є основою для автоматизації цього процесу, що дозволить усунути суб'єктивний фрактор некомпетентності користувача і реалізувати в автоматизованому виді логічну схему поетапного синтезу ШНС.

\section{Література}

1. Айзерлан М.Ф. Метод потенциальных фрункций в теории обучения машин / Айзерман М.Ф., Браверман Э.М., Розоноэр Л.И. - М.: Наука, 1970

2. Барцев С.И. Адаптивные сети обработки информации / Барцев С.И., Охонин В.А. - Красноярск: Ин-т физики СО АН СССР, 1986. Препринт № 59Б. - 20 с.

3. Бонгард М.М. Проблемы узнавания. - М.: Физматгиз, 1967

4. Винер Н. Кибернетика или управление и связь в животном и машине. - М.: Сов. радио, 1968. - 326 с.

5. Галушкин А.И. Синтез многослойных систем распознавания образов. - М.: Энергия. - 1974.

6. Горбань А.Н. Нейроинформатика: кто мы, куда мы идём, как путь наш измерить? // Вычислительные технологии. - М.: Машиностроение. - 2000. - № 4. - С. 10-14

7. Ивахненко А.Г. Метод группового учета аргументов - конкурент метода стохастической аппроксимации // Автоматика. - 1968. - № 3. C. 58-72.

8. Ивахненко А.Г. Самообучающиеся системы распознавания и автоматического управления. - К.: “Техніка", 1969. - 392 с.

9. Ивахненко А.Г. Системы эвристической самоорганизации в технической кибернетике. - К.: “Техніка", 1971. - 372 с.

10. Петров А.П. О возможностях персептрона // Известия АН СССР, Техническая кибернетика. - 1964. - №6

11. Чернодуб А.Н. Обзор методов нейроуправления / Чернодуб А.Н., Дзюба Д.А.//Проблемы программирования. - 2011. - № 2. - С. 79-94 
12. Ялипольский Л.С. Автоматизированные системы технологической подготовки робототехнического производства / Ямпольский Л.С., Калин О.М., Ткач М.М. - К.: Вища шк., 1987. - 271 с.

13. Ялипольский Л.С. Объектно-ориентированный выбор топологии нейросетей при решении прикладных задач / Ямпольский Л.С., Лисовиченко О.И.//Стратегия качества в промышленности и образовании. Материалы VIII Международной конференции, 8-15 мая 2012. - Варна, Болгария: Техничекий ун-т. - 2012. - С. 475 - 478

14. Ялипольский Л.С. Системы искусственного интеллекта в планировании, моделировании и управлении (на укр. яз.) / Ямпольский Л.С., Ткач Б.П., Лисовиченко О.И. - К.: ДП “Вид. Дім “Персонал”, 2011. $-544 \mathrm{c}$.

15. Ackley D.H., Hinton G.E. and Sejnowski T.J. A Learning Algorithm for Boatman Machines // Cognitive Science. - 1985. - 9. - P. 147-169

16. Almeida L.B. A Learning Rule for Asynchronous Perceptrons with Feedback in a Combinatorial Environment // Proc. of the First IEEE International Conference on Neural Networks, USA, SanDiego, 1987. - Vol. 2. - P. 609-618

17. Anderson J.A. Two Models for Memory Organization // Mathematical Biosciences. - 1970. - 8. - P. 137-160

18. Bartsev S.I., Okhonin V.A. The algorithm of dual functioning (backpropagation): general approach, versions and applications. Krasnoyarsk: Biophysics Institute SB AS USSR of, 1989. Preprint, №107B. - 16 p.

19. Bellifemine F.L., Caire G. and Greenwood D. Developing Multi-Agent Systems with JADE. - -Wiley, 2007.

20. Carpenter G.A. and Grossberg S. The ART of Adaptive Pattern Recognition by a Self-Organizing Neural Networks // Computer. - 1988. March. - P. 77-88

21. Carpenter G.A., Grossberg S. and Rosen D.B. Fuzzy ART: Fast Stable Learning and Categorization of Analog Input Patterns by an Adaptive Resonance System // Neural Networks. - 1991. - 4. - P. 759-771

22. Elman J.L. Finding Structure in Time // Cognitive Science. - 1990. - 14. - P. 179-211

23. Fahlman S.E. and Lebiere C. The Cascade-Correlation Learning Architecture / Carnegi Mellon Report. Nr. CMU-CS-88-162, 1990

24. Fukushima K. Neocognitron: A Self-organizing Neural Network for a Mechanism of Pattern Recognition Unaffected by Shift in Position // Biological Cybernetics. - 1980. - 36. - P. 193-202

25. Fukushima K. Cognitron: A Self-organizing Multiplayered Neural Network // Biological Cybernetics. - 1975. - 20. - P. 121-136

26. Grossberg S. Competitive Learning: From Interactive Activation do Adaptive Resonance // Cognitive Science. - 1987. - 11. - P. 23-63 
27. Grossberg S. Nonlinear Neural Networks: Principles, Mechanism and Architectures // Neural Networks, 1988. - V.1. - № 1. - P. 17-62.

28. Haken H., Fuchs A., Banzhatt W. Mustererkennung durch synergetische Computer. Teil 1. Und 2 // Design and Elektronik, 1989

29. Harp S. and Samad T. Genetic Optimization of Neural Networks Architectures for Electric Utility Applications / Final Report. Electric Power Research Institute, Research Project № 8016-04, Palo Alto, CA. March. $-1994$

30. Hecht-Nielsen R. Theory of the Backpropagation Neural Network / Proc. of Int. Joint. Conf. on Neural Networks. - Washington: D. C., 1989. - 1. - P. 593-606

31. Hebb D. The Organization of Behavior. - New York: Willey Publications, 1949

32. Hinton G.E. Connectionist Learning Procedures // Artificial Intelligence. -1989 . - 40. - P. 185-234

33. Holland J.L. Adaptation in Natural and Artificial Systems: An Introductory Analysis with Application to Biology, Control and Artificial Systems. - The University of Michigan Press, Ann Arbor. - 1975

34. Hopfield J.J. Neural Networks and Physical Systems with Emergent Collective Computational Abilities // Proc. of the National Academy of Science. - 1982. - 79. - P. 2554-2558

35. Hopfield J.J. Neurons with Graded Response Have Collective Computational Properties Like Those of Two-State Neurons // Proc. of the National Academy of Science. - 1982. - 81. - P. 3088-3092

36. Jordan M.I. Attractor Dynamics and Parallelism in a Connectionist Sequential Machine // Proc. of the Eight Annual Conference of the Cognitive Science Society, Erlbaum, Hillsdale NJ, 1986. - P. 531-546

37. Kohonen T. Associative Memory: A System Theoretic Approach. - Berlin: Springer, 1977

38. Kohonen T. Self-Organized Formation of Topologically Correct Feature Maps // Biological Cybernetics. - 1982. - 43. - P. 59-69

39. Kosko B. Adaptive Bidirectional Associative Memories // Appl. Optics. 1987. - 26. - № 33. - P. 4947-4960

40. Koza J.P. Genetic Prog ramming: On the Prog ramming of Computers by Means of Natural Selection. - Cambridge, MA, MIT Press, 1992

41. Lang K.J., Waibel A.H. and Hinton G.E. A Time-Delay Neural Network Architecture for Isolated Word Recognition // Neural Network. - 1990. 3. - № 1. - P. 23-43

42. Lippman R.P. An Introduction to Computing with Neural Nets // IEEE ASSP Magazine. - 1987. - № 4. - P. 4-22 
43. Mc Culloch W.S. and Pitts W. A Logical Calculus of the Ideas Immanent in Nervous Activity // Bulletin of Mathematical Biophysics. - 1943. - 5. - P. 115-133

44. Minsky M.L. and Papert S.A. Perceptrons // Cambridge (Mass): MIT press, $1969 .-321 \mathrm{p}$.

45. Nelles O., Ernst S. and Isermann R. Neuronale Netze sur Identifikation nichtlinearer dynamischer Systeme: Ein berblick // Automatisierungstechnik. - 1997. - 45. - № 6. - S. 251-262

46. Patterson D. Artificial Neural Networks: Theory and Application. - Singapore: Prentice Hall Inc., 1996

47. Pham D.T. and Liu X. Modelling and Prediction using GMDH Networks of Adalines with Nonlinear Preprocessors // Intern. Jornal System Science. 1994. - 25. - № 11. - P. 1743-1759

48. Pineda F.J. Dynamic and Architectures for Neural Computation // Journal of Complexity. - 1988. - 4. - P 216-245

49. Powell V.J.D. Radial Basis Functions for Multivariable Interpolation: A review / Proc. of IMA Conf. on Algorithms for the Approximation of Functions and Data, Shrivenham, UK. - 1985. - P. 143-167

50. Rosenblatt F. The Perceptron: A Probabilistic Model for Information Storage and Organization in the Brain // Psychological Review. - 1958. - 65. - P. 386-408

51. Rumelhart D.E., Hilton G.E. and Williams R.J. Learning Internal Representations by Error Propagation / In Parallel Distributed Processing: Explorations in the Microstructure of Cognition. D.E. Rumelhart, J.L. Mc Clelland (Eds). - Cambridge: MitPress, 1986. - Vol. 1. - Chapt. 8. - P. 318-364

52. Waibel A., Hanazava T., Hinton G., Shikano K. And Lang K.J. Phoneme Recognition using Time-Delay Neural Network // IEEE Trans. on Acoustics, Speech and Signal Processing, 1989. - 37. - № 3. - P. 328-339

53. Werbos P.J. Bejond regression: New Tools for Prediction and Analysis in the Behavioral Sciences. Ph.D thesis. - Cambridge, MA, Harvard University, 1974

54. Widrow B. and Hoff M.E. Adaptive Switching Circuits / IRE WESCON Convention Record - New York, IRE, 1960. - P. 96-104

55. Whitley D., Dominic S. and Das R. Genetic Reinforcement Learning with Multilayer Neural Networks / In Belew and Booker. - 1991. - P. 562570

Отримано 10.02.2012 p. 